\title{
Influence of Take-All Epidemics on Winter Wheat Yield Formation and Yield Loss
}

\author{
Alexandra Schoeny, Marie-Hélène Jeuffroy, and Philippe Lucas
}

First and third authors: INRA, UMR BiO3P, Domaine de la Motte, BP 35327, 35653 Le Rheu Cedex, France; and second author: INRA, UMR Agronomie, BP 01, 78850 Thiverval-Grignon, France.

Accepted for publication 31 March 2001.

ABSTRACT

\begin{abstract}
Schoeny, A., Jeuffroy, M.-H., and Lucas, P. 2001. Influence of take-all epidemics on winter wheat yield formation and yield loss. Phytopathology 91:694-701.

The effects of take-all epidemics on winter wheat yield formation were determined, and disease-yield relationships were established to assess the agronomic efficacy and economic benefits of control methods. Epidemics were generated in naturally infested fields by varying cropping season, crop order in the rotation, and experimental fungicide seed treatment. Disease incidence and severity were assessed from tillering to flowering. Yield components were measured at harvest. Models simulating the formation of the yield components in the absence of limiting factors were used to estimate the losses caused by take-all. Losses were
\end{abstract}

predicted by the disease level at a specific time or the area under the disease progress curve, reflecting accumulation during a specific period. Losses of grain number per square meter and 1,000-grain weight were linked to cumulative disease incidence between the beginning of stem elongation and flowering, and disease incidence at midstem elongation, respectively. Yield losses were accounted for by both cumulative disease incidence between sowing and flowering, and disease incidence at midstem elongation. Results confirm the importance of nitrogen fertilization in reducing the impact of take-all on wheat.

Additional keywords: disease threshold, Gaeumannomyces graminis var. tritici, Triticum aestivum.
Take-all, caused by the soilborne fungus Gaeumannomyces graminis (Sacc.) Arx \& D. Olivier var. tritici J. Walker, is a serious root disease of winter wheat (Triticum aestivum L.). Neither breeding for host resistance or tolerance nor massive investment worldwide in research into biocontrol approaches has yet resulted in successful control of the disease. The cultural practices currently available to farmers for limiting infestations include delayed sowing (8), the use of ammoniacal forms of nitrogen (35), rotations involving frequent breaks with nonhost crops (9), and, paradoxically, continuous wheat cropping, which may lead to take-all decline by developing biological suppression of the disease $(14,33)$. However, these practices are not always applicable for technical, economic, or environmental reasons. Chemical control has not been possible because of the lack of effective fungicides but should soon be possible with the launch of new seed treatments targeting take-all $(3,40)$.

Disease-yield relationships must be determined to assess the agronomic efficacy and economic benefits of control methods. Few studies have focused on the relationship between take-all progress and crop response for two main reasons. First, studies based on take-all epidemic development must include a large number of representative samplings because of the patchy distribution of the disease. Because the pathogen is soilborne, disease assessment involves destructive sampling before examination of the root system. Second, epidemic development must be studied in different soil environments to investigate possible effects of the disease on the crop and yield. Previous research has been based on the use of different crop rotations $(32,34)$, sowing dates $(1)$, or artificial inoculations with different amounts of fungal inoculum (29) or with the same amount incorporated at different depths (15)

Corresponding author: A. Schoeny; E-mail address: schoeny@rennes.inra.fr

Publication no. P-2001-0423-01R

(C) 2001 The American Phytopathological Society to generate differences in epidemic patterns. However, these methods introduce additional, uncontrolled variation in treatment effects. These approaches have generally focused on total yield at harvest, but rarely on the various yield components that form successively during the cropping season: ear number per square meter (sowing to midstem elongation), grain number per ear (floral initiation to flowering), grain number per square meter (sowing to flowering), and 1,000-grain weight (flowering to maturity) (25); disease impact on yield is likely to vary according to disease earliness, and consequently, to the nature of the affected yield components. Moreover, most studies simply established correlations between damage (i.e., yield reduction) and disease level measured at flowering (1), grain filling $(15,34)$, or harvest $(21,32)$, but never took into account the dynamic pattern of the disease throughout the crop cycle.

In a previous paper, it was shown that the MON65500 seedtreatment fungicide could be used to obtain different disease incidence (DI) and severity progress curves at a single location with identical cultural practices and climatic conditions (30). Experiments conducted at different locations and in different cropping seasons made it possible to achieve a wide variety of disease scenarios.

The main objective of this study was to investigate the effects of various take-all epidemics on yield formation in relation to disease progress. Because nitrogen is a determining factor in yield formation, a second objective was to see if these effects vary according to nitrogen fertilization.

\section{MATERIALS AND METHODS}

Field experiments. Five field experiments were conducted between 1994 and 1997 near Rennes $\left(48^{\circ} 01^{\prime} \mathrm{N}, 1^{\circ} 43^{\prime} \mathrm{W}\right)$ in western France. They were coded with the initials of the location (LR for Le Rheu or P for Pacé) followed by the order of the assessed wheat crop ( 2 for second wheat crop or 3 for third wheat crop) and the harvest year (95, 96, or 97). The experimental 
design consisted of three to six blocks depending on the experiment. In all experiments except P397, experimental treatments combined three rates of MON65500 seed-treatment fungicide $(0$, 25 , and $50 \mathrm{~g}$ a.i./100 $\mathrm{kg}$ of seeds) and two rates of nitrogen fertilization, corresponding to two yield targets (5.6 to 6.5 and 8 to $8.5 \mathrm{t} / \mathrm{ha})$. The low $\mathrm{N}$ rate $(\mathrm{N}-, 110$ to $135 \mathrm{~kg}$ of $\mathrm{N}$-ammonium nitrate per ha) was applied in two spring applications at growth stages 23 (GS23; tillering) and GS31 (beginning of stem elongation) according to Zadoks' scale (42). The high $\mathrm{N}$ rate $(\mathrm{N}+, 180$ to $195 \mathrm{~kg}$ of $\mathrm{N}$ per ha) was applied in three spring applications at GS23, GS31, and GS33 (midstem elongation). Both rates were calculated using the predictive balance sheet method (27). In P397, experimental treatments combined two strategies of take-all chemical control for 2 years preceding the assessed wheat crop as main plots and three rates of MON65500 seed-treatment fungicide $(0,12.5$, and $25 \mathrm{~g}$ a.i./100 $\mathrm{kg}$ of seeds) as subplots. Indeed, the field was split into two plots: one was sown with untreated seeds during the 1994-1995 and 1995-1996 cropping seasons (NT); and the other was sown with seeds treated with MON41100, a compound related to MON65500, during the 1994-1995 cropping season and MON65500 during the 1995-1996 cropping season (T). The distinction between the two plots was maintained in P397 because they presented differences in the crop response to take-all. Nitrogen fertilizer was applied at a low rate (100 kg of N per ha) in two spring applications at GS23 and GS31. Further information concerning the field experiments is provided in Schoeny and Lucas (30).

Disease assessment and modeling. Plants were sampled from tillering until flowering. In all experiments except LR295, four samples of $25 \mathrm{~cm}$ long $\times 2$ rows were taken per experimental treatment per block at each sampling date. In LR295, a single sample of $50 \mathrm{~cm}$ long $\times 2$ rows was taken per experimental treatment per block. Root systems were washed free of soil, and take-all characteristic symptoms (black stelar discoloration) were sought on 10 randomly chosen plants per sample. DI was calculated as the proportion of plants with symptoms on nodal roots. Disease severity, expressed as take-all index (TAI), was calculated as the proportion of nodal root system with symptoms (30). Incidence and severity data were fitted with nonlinear models for each experiment and experimental treatment (30). An additional disease variable, the area under the disease progress curve (AUDPC), was calculated according to the formula

$$
\operatorname{AUDPC}_{S_{1} S_{2}}=\sum_{t=S_{1}}^{t=S_{2}-d t} \frac{[y(t)+y(t+d t)]}{2} d t
$$

where $y(t)$ represents DI or TAI at time, $t, d t$ is the time interval (expressed in degree days, basis $0^{\circ} \mathrm{C}$ ), and $S_{1}$ and $S_{2}$ are the growth stages (in degree days, basis $0^{\circ} \mathrm{C}$ ) over which the AUDPC is calculated.

Assessment of yield components. Plant number per square meter was calculated from the samples collected throughout the cropping season. At harvest, the sampling method was similar to that previously described in terms of sample size and the number of samples per plot, but plants were cut above the ground because disease assessment was no longer necessary. Ears were cut, counted, dried for $48 \mathrm{~h}$ at $70^{\circ} \mathrm{C}$, and threshed. Grains were dried again for $48 \mathrm{~h}$ at $70^{\circ} \mathrm{C}$, weighed, and counted with an electronic seed counter. Ear number per square meter, grain number per ear, grain number per square meter, 1,000-grain weight at $16 \%$ water content, and grain yield at $16 \%$ water content were calculated.

Calculation of yield losses. Although effective, the MON65500 fungicide did not totally prevent take-all development (30). The lack of a disease-free control made it necessary to use a model simulating yield formation in the absence of limiting factors to calculate the potential value of each yield component (Fig. 1). This model consisted of several submodels corresponding to relationships established by Meynard (23), with parameters set by the ITCF (Institut Technique des Céréales et des Fourrages) for many
French cultivars (11). Parameter values for the two cultivars used in our study (cv. Forby in LR295 and cv. Soissons in all other experiments) are given in Table 1. Relationship 1 is a logarithmic equation simulating ear number per square meter from plant number per square meter between two bounds of plant number per square meter. Relationship 2 simulates grain number per ear from ear number per square meter with a linear equation between two bounds of ear number per square meter. For relationship 3, 1,000grain weight is maximal up to a threshold grain number per square meter, above which 1,000-grain weight decreases linearly with respect to grain number per square meter. The potential values of the yield components were, thus, determined step by step for the various treatments in each experiment. For a given yield component, the loss was calculated as follows: percent loss $=\left[\left(C_{p}-\right.\right.$ $\left.\left.C_{o}\right) / C_{p}\right] \times 100$, where $C_{p}$ is the potential value of the component simulated with the model and $C_{o}$ is the observed value of the component.

These losses reflect the total effect of all limiting factors, nutritional and pathological, during the crop cycle. They were, therefore, corrected by assuming that losses in the absence of disease during yield component formation were attributable to limiting factors other than take-all. Total losses for each yield component were plotted versus disease variables assessed at the end of the yield component formation or AUDPC-type disease variables calculated for the yield component formation period. For instance, total losses of grain number per square meter were corrected by taking into account the take-all level at flowering or

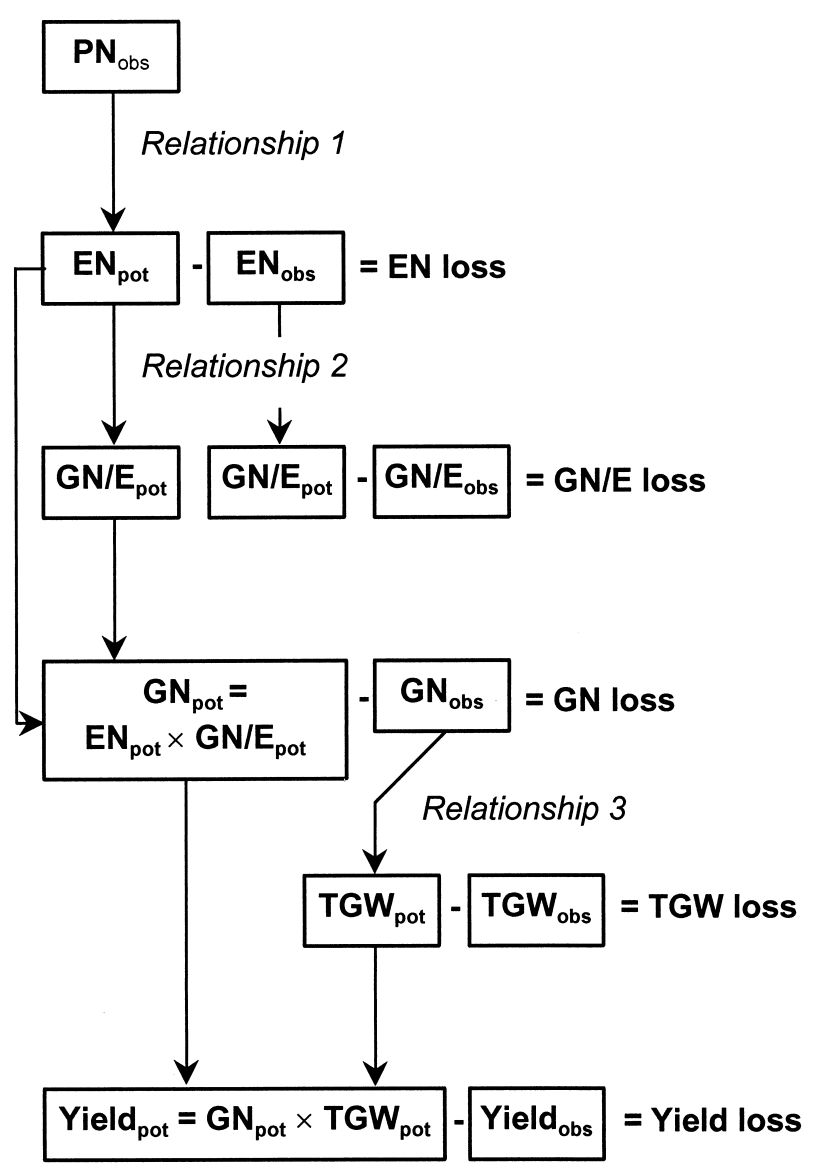

Fig. 1. Model of yield formation established from submodels available in the literature $(11,23)$. PN = plant number per square meter; $\mathrm{EN}=$ ear number per square meter; GN/E = grain number per ear; $\mathrm{TGW}=1,000$-grain weight at $16 \%$ water content; Yield $=$ grain yield at $16 \%$ water content; subscript obs = observed value of the component; and subscript pot = potential value of the component. 
the AUDPC between sowing and flowering. If there was a significant linear relationship between the total loss of the yield component and the disease variable, then the intercept represents the loss attributable to limiting factors other than take-all. If total loss was not linked to the disease variable, then the lowest loss presumably resulted from limiting factors other than take-all. Losses actually caused by take-all were determined by subtracting these additional effects from total losses (Fig. 2).

Statistical analysis and establishment of disease-yield relationships. The effects of experimental factors on take-all incidence and severity at the different sampling dates and yield com-

TABLE 1. Parameters of the relationships between yield components ${ }^{\mathrm{z}}$ for the two cultivars used in the experiments (11)

\begin{tabular}{lcc}
\hline & \multicolumn{2}{c}{ Cultivar } \\
\cline { 2 - 3 } Relationship & Forby & Soissons \\
\hline 1 & $\mathrm{EN}=0.85(565 \log \mathrm{PN}-550)$ & $\mathrm{EN}=565 \log \mathrm{PN}-550$ \\
$\mathrm{PN}_{\min }$ & 100 & 100 \\
$\mathrm{PN}_{\text {max }}$ & 450 & 450 \\
2 & $\mathrm{GN} / \mathrm{E}=0.97(-0.04 \mathrm{EN}+72.28)$ & $\mathrm{GN} / \mathrm{E}=-0.04 \mathrm{EN}+72.28$ \\
$\mathrm{EN}_{\text {min }}$ & 560 & 560 \\
$\mathrm{EN}_{\text {max }}$ & 800 & 800 \\
3 & $\mathrm{TGW}=-0.001865 \mathrm{GN}+100.1$ & $\mathrm{TGW}=-0.0015 \mathrm{GN}+91.6$ \\
$\mathrm{GN}_{\text {threshold }}$ & 23,000 & 29,000 \\
$\mathrm{TGW}_{\text {max }}$ & 57.5 & 48.5
\end{tabular}

${ }^{\mathrm{z}} \mathrm{PN}=$ plant number per square meter; $\mathrm{EN}=$ ear number per square meter; $\mathrm{GN} / \mathrm{E}=$ grain number per ear; $\mathrm{GN}$ = grain number per square meter; and $\mathrm{TGW}=1,000$-grain weight $(\mathrm{g})$ at $16 \%$ water content. ponents at harvest were tested for each experiment by analyses of variance using the GLM (general linear model) procedure of the SAS software package (SAS Institute Inc., Cary, NC). Models and error terms to test the effects were chosen according to experimental designs (randomized complete block in LR295, split-plot with seed treatment as main plots in LR296 and LR396, and splitplot with seed treatment as subplots in P297 and P397). Means for significant effects were compared by Fisher's protected least significant difference test.

Two kinds of disease variables were considered in the determination of disease-yield relationships: (i) instantaneous, DI and TAI assessed at GS23, GS31, GS33, and GS65; and (ii) cumulative, $\mathrm{AUDPC}_{\mathrm{DI}}$ and $\mathrm{AUDPC}_{\mathrm{TAI}}$ calculated for various periods (e.g., sowing-GS23, sowing-GS31, and GS23 to GS31). Regression models involving these disease variables were compared to test their ability to account for, and to predict, subsequent yield component losses. Regression analyses were done on the means (across the replications) of experimental treatments. They were performed separately for $\mathrm{N}$ - and $\mathrm{N}+$ treatments, assuming that the losses caused by take-all vary according to nitrogen fertilization. Intercepts were removed from complete regression models if not significantly different from zero at $P=0.05$. Parameter estimates were compared for $\mathrm{N}-$ and $\mathrm{N}+$ treatments by the Student's $t$ test. When slopes and intercepts were not significantly different, $\mathrm{N}-$ and $\mathrm{N}+$ data were pooled and a single regression model was sought. When slopes or intercepts were significantly different, regression models were chosen separately for $\mathrm{N}-$ and $\mathrm{N}+$ treatments. Only models accounting for the largest proportion of variability (highest coefficients of determination) are presented.
A

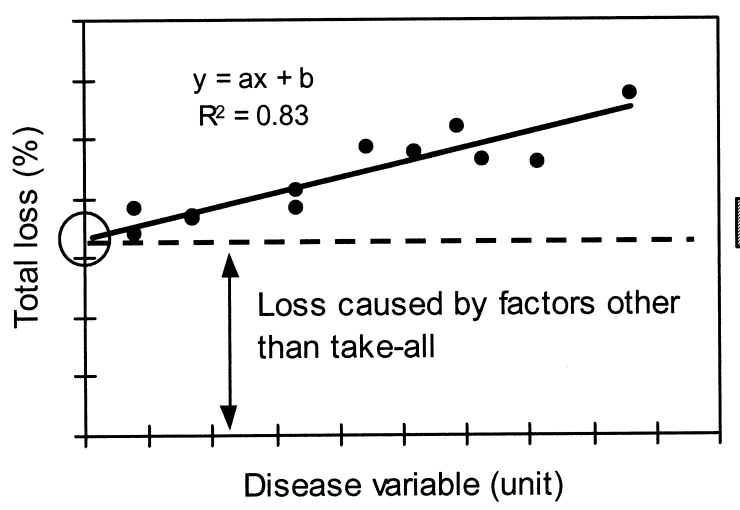

B

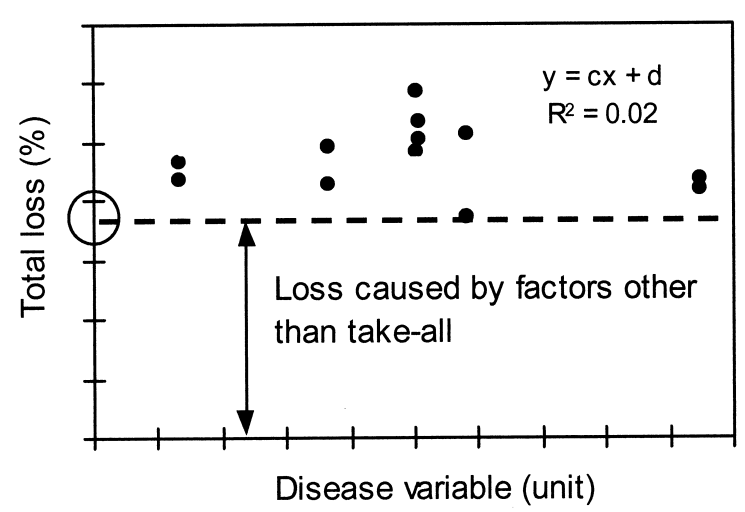

After correction

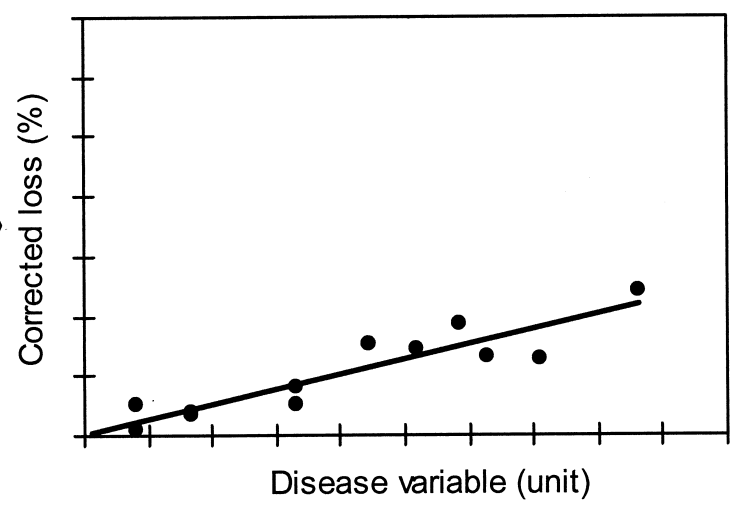

After correction

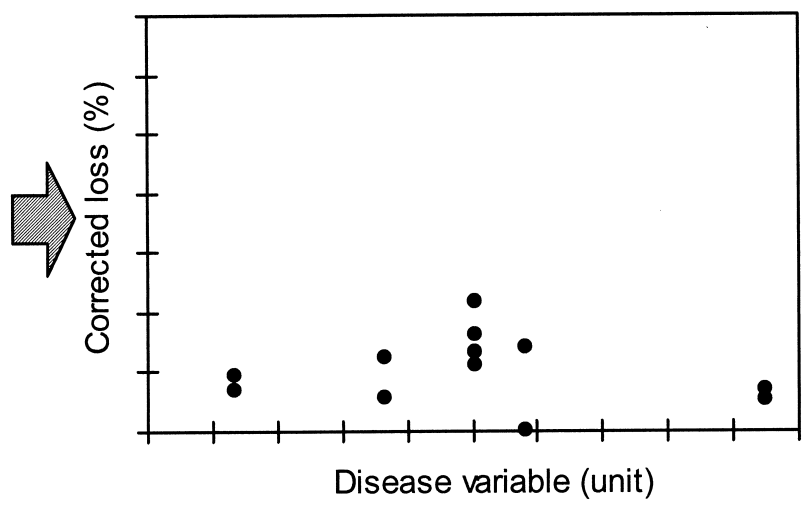

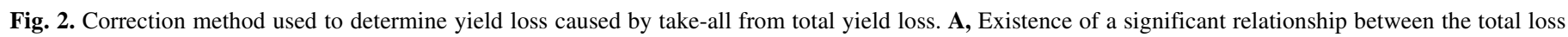
and the disease variable; and $\mathbf{B}$, absence of a significant relationship between the total loss and the disease variable. 


\section{RESULTS}

Effect of experimental factors on disease variables. Only the main effects are presented because no fungicide-nitrogen fertilization or fungicide-previous chemical control interaction was significant. The effect of MON65500 seed-treatment fungicide on take-all incidence and severity has been described in detail in Schoeny and Lucas (36) for N+ and NT treatments. According to the onset of infection (assessed with DI at GS23) and severity progress (assessed with TAI at GS65) in untreated plots (M0), take-all epidemics were classified as early and severe (LR295), late and slight (LR296 and LR396), late and moderate (P297), and late and severe (P397). Treated plots showed significantly reduced disease levels compared with untreated plots, as soon as GS23 or later, depending on epidemics (Tables 2 and 3).

Nitrogen rate had no effect on take-all development, except in P297 where DI was significantly increased in N+ plots. In P397,

TABLE 2. Effect of experimental factors on take-all incidence (proportion of diseased plants) of wheat at various growth stages in field experiments conducted in France in 1994 to $1997^{\mathrm{v}}$

\begin{tabular}{|c|c|c|c|c|c|c|}
\hline \multirow[b]{2}{*}{ Exp. } & \multirow{2}{*}{$\begin{array}{l}\text { Experimental } \\
\text { factor }\end{array}$} & \multirow{2}{*}{$\begin{array}{l}\text { Rate of } \\
\text { factor }^{\mathrm{w}}\end{array}$} & \multicolumn{4}{|c|}{ Growth stage ${ }^{\mathrm{x}}$} \\
\hline & & & GS23 & GS31 & GS33 & GS65 \\
\hline \multirow[t]{7}{*}{ LR295 } & Fungicide & M0 & $53 \mathrm{a}$ & $78 \mathrm{a}$ & $92 \mathrm{a}$ & $100 \mathrm{a}$ \\
\hline & & M25 & $21 \mathrm{~b}$ & $54 \mathrm{~b}$ & $90 \mathrm{a}$ & $100 \mathrm{a}$ \\
\hline & & M50 & $16 \mathrm{~b}$ & $48 \mathrm{~b}$ & $72 \mathrm{~b}$ & $91 \mathrm{~b}$ \\
\hline & & $P$ value & 0.0001 & 0.0026 & 0.0045 & 0.0088 \\
\hline & $\mathrm{N}$ fertilization & $\mathrm{N}-$ & $\ldots{ }^{y}$ & $\ldots$ & $83 a$ & $98 \mathrm{a}$ \\
\hline & & & $\ldots$ & $\ldots$ & $86 \mathrm{a}$ & $96 \mathrm{a}$ \\
\hline & & $P$ value & $\ldots$ & $\ldots$ & 0.5819 & 0.4342 \\
\hline \multirow[t]{7}{*}{ LR296 } & Fungicide & M0 & $1 \mathrm{a}$ & $11 \mathrm{a}$ & $47 \mathrm{a}$ & $70 \mathrm{a}$ \\
\hline & & M25 & $0 \mathrm{a}$ & $7 \mathrm{a}$ & $25 \mathrm{~b}$ & $59 \mathrm{a}$ \\
\hline & & M50 & $0 \mathrm{a}$ & $2 \mathrm{a}$ & $25 \mathrm{~b}$ & $67 \mathrm{a}$ \\
\hline & & $P$ value & 0.4444 & 0.2101 & 0.0542 & 0.2131 \\
\hline & $\mathrm{N}$ fertilization & $\mathrm{N}-$ & $\ldots$ & $\ldots$ & $\ldots$ & $65 \mathrm{a}$ \\
\hline & & $\mathrm{N}+$ & $\ldots$ & $\ldots$ & $\ldots$ & $65 \mathrm{a}$ \\
\hline & & $P$ value & $\ldots$ & $\ldots$ & $\ldots$ & 0.9536 \\
\hline \multirow[t]{7}{*}{ LR396 } & Fungicide & M0 & $0 \mathrm{a}$ & $5 a$ & $29 \mathrm{a}$ & $60 \mathrm{a}$ \\
\hline & & M25 & $0 \mathrm{a}$ & $3 a$ & $18 \mathrm{a}$ & $51 \mathrm{ab}$ \\
\hline & & M50 & $0 \mathrm{a}$ & $3 \mathrm{a}$ & $7 \mathrm{a}$ & $36 \mathrm{~b}$ \\
\hline & & $P$ value & $\mathrm{nd}^{\mathrm{z}}$ & 0.5017 & 0.1618 & 0.0629 \\
\hline & $\mathrm{N}$ fertilization & $\mathrm{N}-$ & $\ldots$ & $\ldots$ & $\ldots$ & $47 \mathrm{a}$ \\
\hline & & $\mathrm{N}+$ & $\ldots$ & $\ldots$ & $\ldots$ & $51 \mathrm{a}$ \\
\hline & & $P$ value & $\ldots$ & $\ldots$ & $\ldots$ & 0.6633 \\
\hline \multirow[t]{7}{*}{ P297 } & Fungicide & M0 & $1 \mathrm{a}$ & $3 a$ & $33 \mathrm{a}$ & $88 \mathrm{a}$ \\
\hline & & M25 & $0 \mathrm{a}$ & $3 a$ & $17 \mathrm{ab}$ & $86 a$ \\
\hline & & M50 & $0 \mathrm{a}$ & $1 \mathrm{a}$ & $8 \mathrm{~b}$ & $78 \mathrm{a}$ \\
\hline & & $P$ value & 0.4219 & 0.7511 & 0.0519 & 0.2443 \\
\hline & $\mathrm{N}$ fertilization & $\mathrm{N}-$ & $\ldots$ & $\ldots$ & $\ldots$ & $79 \mathrm{~b}$ \\
\hline & & $\mathrm{N}+$ & $\ldots$ & $\ldots$ & $\ldots$ & 89 a \\
\hline & & $P$ value & $\ldots$ & $\ldots$ & $\ldots$ & 0.0787 \\
\hline \multirow[t]{7}{*}{ P397 } & Fungicide & M0 & $8 \mathrm{a}$ & $34 \mathrm{a}$ & $79 a$ & $98 \mathrm{a}$ \\
\hline & & M12.5 & $7 \mathrm{ab}$ & $28 \mathrm{ab}$ & $61 \mathrm{~b}$ & $93 \mathrm{~b}$ \\
\hline & & M25 & $3 \mathrm{~b}$ & $19 \mathrm{~b}$ & $48 \mathrm{c}$ & $81 \mathrm{c}$ \\
\hline & & $P$ value & 0.0673 & 0.0727 & 0.0002 & 0.0001 \\
\hline & Previous & NT & $5 \mathrm{a}$ & $30 \mathrm{a}$ & $62 \mathrm{a}$ & $90 \mathrm{a}$ \\
\hline & treatment & $\mathrm{T}$ & $7 \mathrm{a}$ & $24 \mathrm{a}$ & $63 \mathrm{a}$ & $92 \mathrm{a}$ \\
\hline & & $P$ value & 0.3770 & 0.2285 & 0.8056 & 0.4006 \\
\hline
\end{tabular}

${ }^{\mathrm{v}}$ For each experiment and experimental factor, means within a column followed by the same letter are not significantly different at the given $P$ value according to Fisher's protected least significant difference test.

${ }^{\mathrm{w}}$ M0, M12.5, M25, and M50 = increasing rates of MON65500 seedtreatment fungicide; $\mathrm{N}_{-}=$low nitrogen fertilization; $\mathrm{N}_{+}=$high nitrogen fertilization; NT $=$ no previous seed treatment; and $\mathrm{T}=$ previous seed treatment.

x Wheat growth stage according to Zadoks' scale (42): 00 to 09, germination; 10 to 19 , seedling and main stem elongation; 20 to 29 , tillering; 30 to 39 , stem elongation; 40 to 49 , booting; 50 to 59, inflorescence emergence; 60 to 69 , flowering; 70 to 87 , grain filling; and 90 to 99 , ripening.

y $\mathrm{N}-$ and $\mathrm{N}+$ treatments were similar at this growth stage.

$\mathrm{z}$ Variance was zero (nd = not determined). no significant effect of previous chemical control on take-all development was detected (Tables 2 and 3).

Effect of experimental factors on yield components. No fungicide-nitrogen fertilization or fungicide-previous chemical control interaction was significant. Yield was significantly increased in M25-treated plots in P297 and P397, and in M50-treated plots in LR295 and P297. The components of yield recovery depended on the earliness and severity of take-all epidemics. In LR296, LR396, and P297 (late and slight to moderate epidemics), increased yields were obtained due to an increase in 1,000-grain weight, whereas no significant effect was detected on grain number per square meter (Table 4). In LR295 (early and severe epidemic), increased yields were accounted for by an increase in grain number per square meter, and in P397 (late and severe epidemic) by increases in both grain number per square meter and 1,000 -grain weight. Increases in grain number per square meter resulted mainly from an increase in grain number per ear.

TABLE 3. Effect of experimental factors on take-all index (proportion of necrotic nodal root system) of wheat at various growth stages in field experiments in France in 1994 to $1997^{v}$

\begin{tabular}{|c|c|c|c|c|c|c|}
\hline \multirow[b]{2}{*}{ Exp. } & \multirow{2}{*}{$\begin{array}{l}\text { Experimental } \\
\text { factor }\end{array}$} & \multirow{2}{*}{$\begin{array}{l}\text { Rate of } \\
\text { factor }^{\mathrm{W}}\end{array}$} & \multicolumn{4}{|c|}{ Growth stage ${ }^{\mathrm{x}}$} \\
\hline & & & GS23 & GS31 & GS33 & GS65 \\
\hline \multirow[t]{7}{*}{ LR295 } & Fungicide & M0 & $5 a$ & $19 a$ & $35 \mathrm{a}$ & $58 \mathrm{a}$ \\
\hline & & M25 & $1 \mathrm{~b}$ & $4 \mathrm{~b}$ & $15 \mathrm{~b}$ & $43 \mathrm{~b}$ \\
\hline & & M50 & $1 \mathrm{~b}$ & $5 \mathrm{~b}$ & $5 \mathrm{~b}$ & $17 \mathrm{c}$ \\
\hline & & $P$ value & 0.0003 & 0.0046 & 0.0001 & 0.0001 \\
\hline & $\mathrm{N}$ fertilization & $\mathrm{N}-$ & $\ldots^{\mathrm{y}}$ & $\ldots$ & 19 a & $42 \mathrm{a}$ \\
\hline & & & $\ldots$ & $\ldots$ & $18 \mathrm{a}$ & $36 \mathrm{a}$ \\
\hline & & $P$ value & $\ldots$ & $\ldots$ & 0.8042 & 0.2955 \\
\hline \multirow[t]{7}{*}{ LR296 } & Fungicide & M0 & $0 \mathrm{a}$ & $1 \mathrm{a}$ & $3 a$ & $13 \mathrm{a}$ \\
\hline & & M25 & $0 \mathrm{a}$ & $0 \mathrm{a}$ & $1 \mathrm{~b}$ & $7 \mathrm{~b}$ \\
\hline & & M50 & $0 \mathrm{a}$ & $0 \mathrm{a}$ & $1 \mathrm{~b}$ & $5 \mathrm{~b}$ \\
\hline & & $P$ value & 0.4444 & 0.2101 & 0.0308 & 0.0137 \\
\hline & $\mathrm{N}$ fertilization & $\mathrm{N}-$ & $\ldots$ & $\ldots$ & $\ldots$ & $8 \mathrm{a}$ \\
\hline & & $\mathrm{N}+$ & $\ldots$ & $\ldots$ & $\ldots$ & $9 \mathrm{a}$ \\
\hline & & $P$ value & $\ldots$ & $\ldots$ & $\ldots$ & 0.6608 \\
\hline \multirow[t]{7}{*}{ LR396 } & Fungicide & M0 & $0 \mathrm{a}$ & $0 \mathrm{a}$ & $2 \mathrm{a}$ & $7 \mathrm{a}$ \\
\hline & & M25 & $0 \mathrm{a}$ & $0 \mathrm{a}$ & $1 \mathrm{a}$ & $4 \mathrm{a}$ \\
\hline & & M50 & $0 \mathrm{a}$ & $0 \mathrm{a}$ & $0 \mathrm{a}$ & $2 \mathrm{a}$ \\
\hline & & $P$ value & $\mathrm{nd}^{\mathrm{z}}$ & 0.5017 & 0.1826 & 0.3238 \\
\hline & $\mathrm{N}$ fertilization & $\mathrm{N}-$ & $\ldots$ & $\ldots$ & $\ldots$ & $4 a$ \\
\hline & & $\mathrm{N}+$ & $\ldots$ & $\ldots$ & $\ldots$ & $4 \mathrm{a}$ \\
\hline & & $P$ value & $\ldots$ & $\ldots$ & $\ldots$ & 0.5978 \\
\hline \multirow[t]{7}{*}{ P297 } & Fungicide & M0 & $0 \mathrm{a}$ & $0 \mathrm{a}$ & $2 \mathrm{a}$ & $24 \mathrm{a}$ \\
\hline & & M25 & $0 \mathrm{a}$ & $0 \mathrm{a}$ & $1 \mathrm{ab}$ & $11 \mathrm{~b}$ \\
\hline & & M50 & $0 \mathrm{a}$ & $0 \mathrm{a}$ & $0 \mathrm{~b}$ & $5 \mathrm{~b}$ \\
\hline & & $P$ value & 0.4219 & 0.7511 & 0.0812 & 0.0172 \\
\hline & $\mathrm{N}$ fertilization & $\mathrm{N}-$ & $\ldots$ & $\ldots$ & $\ldots$ & $9 \mathrm{a}$ \\
\hline & & $\mathrm{N}+$ & $\cdots$ & $\ldots$ & $\cdots$ & $17 \mathrm{a}$ \\
\hline & & $P$ value & $\ldots$ & $\ldots$ & $\ldots$ & 0.1046 \\
\hline \multirow[t]{7}{*}{ P397 } & Fungicide & M0 & $1 \mathrm{a}$ & $2 \mathrm{a}$ & $11 \mathrm{a}$ & $32 \mathrm{a}$ \\
\hline & & M12.5 & $0 \mathrm{~b}$ & $2 \mathrm{a}$ & $5 \mathrm{~b}$ & $21 \mathrm{~b}$ \\
\hline & & M25 & $0 \mathrm{~b}$ & $1 \mathrm{a}$ & $4 b$ & $9 c$ \\
\hline & & $P$ value & 0.0490 & 0.1265 & 0.0001 & 0.0001 \\
\hline & Previous & NT & $0 \mathrm{a}$ & $2 a$ & $7 \mathrm{a}$ & $21 \mathrm{a}$ \\
\hline & treatment & $\mathrm{T}$ & $0 \mathrm{a}$ & $2 \mathrm{a}$ & $6 \mathrm{a}$ & $20 \mathrm{a}$ \\
\hline & & $P$ value & 0.2320 & 0.6624 & 0.4585 & 0.6671 \\
\hline
\end{tabular}

${ }^{\mathrm{v}}$ For each experiment and experimental factor, means within a column followed by the same letter are not significantly different at the given $P$ value according to Fisher's protected least significant difference test.

${ }^{\mathrm{w}} \mathrm{M} 0, \mathrm{M} 12.5$, M25, and M50 = increasing rates of MON65500 seedtreatment fungicide; $\mathrm{N}-=$ low nitrogen fertilization; $\mathrm{N}_{+}=$high nitrogen fertilization; $\mathrm{NT}=$ no previous seed treatment; and $\mathrm{T}=$ previous seed treatment.

x Wheat growth stage according to Zadoks' scale (42): 00 to 09, germination; 10 to 19 , seedling and main stem elongation; 20 to 29 , tillering; 30 to 39 , stem elongation; 40 to 49 , booting; 50 to 59 , inflorescence emergence; 60 to 69 , flowering; 70 to 87 , grain filling; and 90 to 99 , ripening.

y $\mathrm{N}-$ and $\mathrm{N}+$ treatments were similar at this growth stage.

${ }^{\mathrm{z}}$ Variance was zero (nd $=$ not determined). 
The effect of nitrogen fertilization on yield was inconsistent. In LR295, yield was significantly greater in $\mathrm{N}+$ plots than in $\mathrm{N}-$ plots, due to a significant increase in all yield components except 1,000-grain weight. In LR296, no significant effect of nitrogen dose was detected. In LR396, no individual yield component was significantly increased in $\mathrm{N}+$ plots, but almost all were slightly greater, leading to a significantly larger yield. In P297, yield was significantly greater in $\mathrm{N}+$ plots and yield increase was accounted for by significant increases in all yield components except ear number per square meter. In P397, yield, grain number per square meter, and ear number per square meter were significantly larger in NT plots (without fungicide protection in the 2 years preceding the experiment) than in T plots (with fungicide protection).

Disease-yield relationships. Losses of ear number per square meter were linked to cumulative DI between the beginning of stem elongation (GS31) and flowering (GS65) (Fig. 3A). The linear model accounted for $73 \%$ of the variability for the low nitrogen rate. The fit was less good for the high rate $\left(R^{2}=61 \%\right)$ but, nevertheless, suggested that for similar disease levels, the losses of ear number per square meter were reduced by $37 \%$ in plots on which a high rate of nitrogen was applied. The losses of grain number per ear observed in $\mathrm{N}$ - plots were partially accounted for $\left(R^{2}=74 \%\right)$ by the disease variable AUDPC $\mathrm{DI}_{\mathrm{DI}}$, calculated between sowing and flowering (Fig. 3B); no relationship emerged for the $\mathrm{N}+$ data because the losses were very low in most cases $\left(R^{2}=31 \%\right)$. Losses of grain number per square meter were linked to cumulative DI between sowing and flowering (data not shown) and, more particularly, between the beginning of stem elongation and flowering (Fig. 3C). A minimum disease threshold (i.e., a disease level beyond which the component is affected) was identified. It corresponded to the disease value ( $x$ coordinate) at which the predicted component loss from the regression analysis is zero. The disease threshold was significantly increased by the high rate of nitrogen fertilization: it was 0 for the $\mathrm{N}$ - rate and 130 for the $\mathrm{N}+$ rate (corresponding to, for example, a cumulative DI of $10 \%$ for 1,300 degree days). Losses of 1,000-grain weight were linked to DI at midstem elongation by a linear relationship accounting for $92 \%$ of the variability (Fig. 3D). Unlike the other components, 1,000-grain weight showed no differential response according to the level of nitrogen fertilization. Yield losses were strongly linked to the $\mathrm{AUDPC}_{\mathrm{DI}}$ calculated between sowing and flowering (Fig. 4A), and to DI at midstem elongation (Fig. 4B). For both disease variables, the losses observed for $\mathrm{N}-$ plots were greater than those observed for $\mathrm{N}+$ plots.

\section{DISCUSSION}

The efficacy of seed treatment, demonstrated by Schoeny and Lucas (30), led to substantial yield recoveries. Yield recovery was

TABLE 4. Effect of experimental factors on yield components of wheat in field experiments in France in 1994 to $1997^{x}$

\begin{tabular}{|c|c|c|c|c|c|c|c|}
\hline \multirow[b]{2}{*}{ Experiment } & \multirow[b]{2}{*}{ Experimental factor } & \multirow[b]{2}{*}{ Rate of factor ${ }^{y}$} & \multicolumn{5}{|c|}{ Yield component $^{\mathrm{z}}$} \\
\hline & & & EN & $\mathrm{GN} / \mathrm{E}$ & GN & TGW & Yield \\
\hline \multirow[t]{5}{*}{ LR295 } & Fungicide & M0 & $417 \mathrm{a}$ & $36.9 \mathrm{~b}$ & $15,618 \mathrm{~b}$ & $38.6 \mathrm{a}$ & $6.06 \mathrm{~b}$ \\
\hline & & M25 & $427 \mathrm{a}$ & $41.3 \mathrm{a}$ & $17,630 \mathrm{ab}$ & $38.4 \mathrm{a}$ & $6.78 \mathrm{ab}$ \\
\hline & & $P$ value & 0.5382 & 0.0169 & 0.0818 & 0.5834 & 0.0937 \\
\hline & $\mathrm{N}$ fertilization & $\mathrm{N}-$ & $408 \mathrm{~b}$ & $38.7 \mathrm{~b}$ & $15,918 \mathrm{~b}$ & 38.8 a & $6.24 \mathrm{~b}$ \\
\hline & & & $448 \mathrm{a}$ & $41.4 \mathrm{a}$ & $18,554 \mathrm{a}$ & $38.4 \mathrm{a}$ & $7.12 \mathrm{a}$ \\
\hline \multirow{6}{*}{ LR296 } & & M25 & $574 \mathrm{a}$ & $35.9 \mathrm{a}$ & $20,412 \mathrm{a}$ & $40.6 \mathrm{ab}$ & $8.32 \mathrm{a}$ \\
\hline & & M50 & $581 \mathrm{a}$ & $35.7 \mathrm{a}$ & 20,826 a & $41.6 \mathrm{a}$ & $8.69 \mathrm{a}$ \\
\hline & & $P$ value & 0.3196 & 0.1791 & 0.9310 & 0.0993 & 0.4773 \\
\hline & $\mathrm{N}$ fertilization & $\mathrm{N}-$ & $582 \mathrm{a}$ & $34.7 \mathrm{a}$ & $20,133 \mathrm{a}$ & $40.4 \mathrm{a}$ & $8.16 \mathrm{a}$ \\
\hline & & $\mathrm{N}+$ & $598 \mathrm{a}$ & $35.5 \mathrm{a}$ & $21,132 \mathrm{a}$ & $39.7 \mathrm{a}$ & $8.44 \mathrm{a}$ \\
\hline & & $P$ value & 0.5107 & 0.4413 & 0.2881 & 0.6127 & 0.6000 \\
\hline \multirow{3}{*}{ LR396 } & $\mathrm{N}$ fertilization & $\mathrm{N}-$ & $610 \mathrm{a}$ & $34.2 \mathrm{a}$ & $20,771 \mathrm{a}$ & $43.6 \mathrm{a}$ & $9.11 \mathrm{~b}$ \\
\hline & & $\mathrm{N}+$ & $634 \mathrm{a}$ & $35.5 \mathrm{a}$ & $22,357 \mathrm{a}$ & 44. $2 \mathrm{a}$ & $10.03 \mathrm{a}$ \\
\hline & & $P$ value & 0.2498 & 0.4625 & 0.1659 & 0.4479 & 0.0766 \\
\hline \multirow[t]{7}{*}{ P297 } & Fungicide & M0 & $529 \mathrm{a}$ & $41.4 \mathrm{a}$ & $21,840 \mathrm{a}$ & $47.6 \mathrm{~b}$ & $10.42 \mathrm{~b}$ \\
\hline & & M25 & $555 \mathrm{a}$ & $41.5 \mathrm{a}$ & $22,779 \mathrm{a}$ & $49.4 \mathrm{ab}$ & $11.23 \mathrm{a}$ \\
\hline & & M50 & $562 \mathrm{a}$ & $39.8 \mathrm{a}$ & $22,247 \mathrm{a}$ & $50.7 \mathrm{a}$ & $11.31 \mathrm{a}$ \\
\hline & & $P$ value & 0.4219 & 0.1258 & 0.5839 & 0.0208 & 0.0530 \\
\hline & $\mathrm{N}$ fertilization & $\mathrm{N}-$ & $538 \mathrm{a}$ & $40.0 \mathrm{~b}$ & $21,359 \mathrm{~b}$ & $47.9 \mathrm{~b}$ & $10.24 \mathrm{~b}$ \\
\hline & & $\mathrm{N+}$ & $559 \mathrm{a}$ & $41.8 \mathrm{a}$ & $23,218 \mathrm{a}$ & $50.6 \mathrm{a}$ & $11.73 \mathrm{a}$ \\
\hline & & $P$ value & 0.3543 & 0.0169 & 0.0207 & 0.0047 & 0.0001 \\
\hline \multirow[t]{3}{*}{ P397 } & Fungicide & M0 & $441 \mathrm{a}$ & $36.3 \mathrm{a}$ & $14,691 \mathrm{~b}$ & $33.3 \mathrm{c}$ & $4.92 \mathrm{~b}$ \\
\hline & & M12.5 & $432 \mathrm{a}$ & $37.7 \mathrm{a}$ & $16,346 \mathrm{ab}$ & $36.3 \mathrm{~b}$ & $5.99 \mathrm{ab}$ \\
\hline & & M25 & $409 \mathrm{a}$ & $39.1 \mathrm{a}$ & $17,374 \mathrm{a}$ & $38.4 \mathrm{a}$ & $6.70 \mathrm{a}$ \\
\hline
\end{tabular}

${ }^{\mathrm{x}}$ For each experiment and yield component, means followed by the same letter are not significantly different at the given $P$ value according to Fisher's protected least significant difference test.

${ }^{\text {y }}$ M0, M12.5, M25, and M50 = increasing rates of MON65500 seed-treatment fungicide; $\mathrm{N}-=$ low nitrogen fertilization; $\mathrm{N}+=$ high nitrogen fertilization; $\mathrm{NT}=$ no previous seed treatment; and $\mathrm{T}=$ previous seed treatment.

${ }^{\mathrm{z}} \mathrm{EN}=$ ear number per square meter; GN/E = grain number per ear; $\mathrm{GN}=$ grain number per square meter; TGW $=1,000$-grain weight $(\mathrm{g})$ at $16 \%$ water content; and Yield $=$ grain yield $(\mathrm{t} / \mathrm{ha})$ at $16 \%$ water content. 
greater in experiments in which take-all epidemics were severe ( 0.72 to $1.78 \mathrm{t} / \mathrm{ha})$ than in experiments in which epidemics were slight to moderate (0.14 to $0.80 \mathrm{t} / \mathrm{ha}$ ). Similar differences in yield response according to epidemic severity were described by Spink et al. (37).

Disease-yield relationships are generally determined from field experiments of plots with and without chemical control. In such experiments, yield losses are determined by comparison of the protected, healthy crop and the unprotected, diseased crop $(6,39)$. In our experiments, seed treatment with fungicide did not eradicate take-all. The lack of a healthy control precluded direct intraand interexperiment comparisons and made it necessary to use other systems of reference to calculate yield component losses caused by take-all. For yield, one method involves comparing the experimental values to a potential value determined from a first wheat crop (2). For this method to be valid, the first wheat crop must meet two conditions: (i) it must be situated in the vicinity of the experiment so it has the same pedoclimatic conditions; and (ii) it must be managed with the same cultural practices (e.g., sowing date, sowing rate, and nitrogen fertilization). In addition to the technical difficulty involved in finding such a plot, this method has two limitations: (i) the potential yield of a first wheat crop depends on the previous crop, and is particularly affected by the quantity of mineral nitrogen remaining in the soil; and (ii) even a first wheat crop may exhibit significant levels of take-all, depending on its cultural history, not just on the immediately preceding crop $(7,19)$. Another possible method for calculating yield losses in the absence of a disease-free control involves using the linear relationships between yield and disease levels to infer the potential yield from the $y$-axis intercept (10). However, such linear relationships are not systematically obtained (1) and this approach is not applicable to yield components that are linked to one another by competition relationships (31); a severe loss of a component determined early in the crop cycle must not lead to the loss of a subsequent component. In this study, we used a model of yield formation that included several submodels to calculate the potential value of a yield component from the observed value of the previous component. These submodels have already been successfully used to quantify the effects of various limiting factors $(4,24)$

Simple linear regression models involving various disease variables were compared and their ability to account for and predict the losses of yield components was assessed. Losses of ear number per square meter, grain number per ear, and grain number per square meter were mainly related to cumulative DI during periods corresponding to yield component formation (sowing to midstem elongation, floral initiation to flowering, and sowing to flowering, respectively). In contrast, 1,000-grain weight losses were linked to DI assessed at midstem elongation (i.e., at a growth stage before the formation of this yield component, grain filling). This relationship is particularly interesting because of its predictive nature.

As take-all affects the root system, it presumably affects the formation of ear number per square meter, grain number per ear, and grain number per square meter by disrupting the nitrogen uptake of plants. This assumption is consistent with the fact that early nitrogen deficiency leads to interruption of the tillering process and reduction of the growth rate of the youngest tillers, reducing the number of elongating tillers and, thus, the ear number per square meter component (22). Later, nitrogen deficiency may affect the grain number per ear by reducing spikelet number or by increasing floret abortion $(18,41)$. The decrease in grain number per square meter depends heavily on the duration and intensity of nitrogen deficiency (17). Thousand-grain weight seems sensitive to early disruptions of crop functioning. Carbon and nitrogen assimilates are generally the limiting factors for 1,000-grain weight (12). Starch accumulation in the grain results mainly from postflowering photosynthesis by organs that are still green and, to a lesser extent, from remobilization of carbon assimilates from stems and leaves. In contrast, the amino acids that make up the grain proteins originate largely from remobilization from stems and leaves following the degradation of proteins stored before flowering $(20,36)$. Therefore, the early effect of take-all on 1,000-
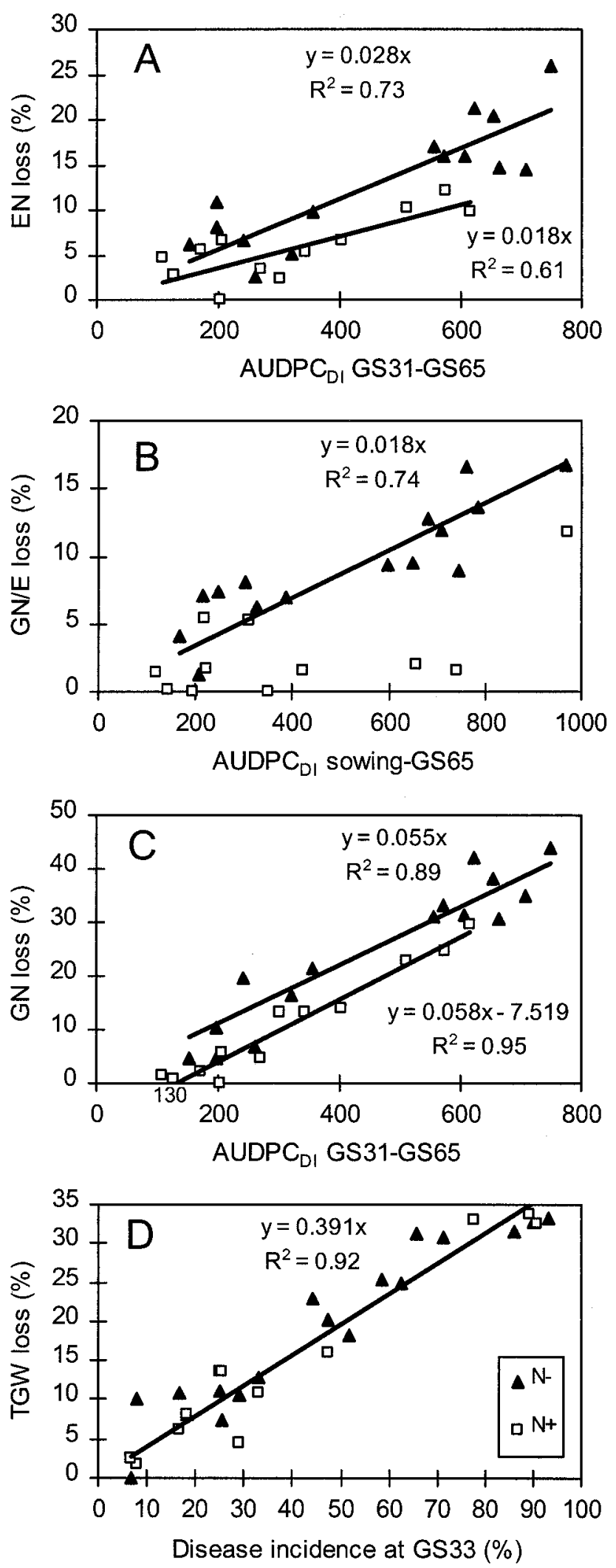

Fig. 3. Disease-yield component loss relationships established from field experiments conducted in France in 1994 to 1997. A, Ear number per square meter; $\mathbf{B}$, grain number per ear; $\mathbf{C}$, grain number per square meter; and D, 1,000-grain weight. $\mathrm{N}_{-}=$low nitrogen fertilization; and $\mathrm{N}_{+}=$high nitrogen fertilization. 
grain weight may be due to an effect on nitrogen storage before flowering and on green leaf area at flowering. Take-all induces early senescence, reducing the persistence of green tissues and the photosynthetic capacity of plants during grain filling $(13,37)$.

The models that accounted for most of the variability in yield reflected the effect of take-all on the two main yield components, grain number per square meter and 1,000-grain weight. Yield losses were linked to cumulative DI between sowing and flowering (one of the explicative disease variables for the loss of grain number per square meter) and DI at midstem elongation (explicative disease variable for the loss of 1,000-grain weight). Yield loss may thus be estimated as early as midstem elongation. This result contrasts with the conclusions of most previous studies. Although there is no consensus as to when take-all assessment should be done to estimate yield loss, late disease assessments are generally thought to be the most indicative of yield (16). Various studies have established correlations between yield and DI or severity assessed at inflorescence emergence $(10,28)$, flowering (1), grain filling $(15,34)$, and harvest $(21,32)$. Correlations between yield and early disease assessment have seldom been reported $(15,16)$.

The losses of ear number per square meter, grain number per ear, grain number per square meter, and yield were successfully accounted for by AUDPC-type disease variables, demonstrating that losses result from the cumulative effects of the disease. AUDPC takes disease progress into account and reflects the accumulation of disease during a specific period, whereas an instantaneous assessment provides the disease level at a specific time but does not reflect the prior progression of the disease, which may be variable. Early DI assessment, however, seems to predict the loss of 1,000-grain weight.
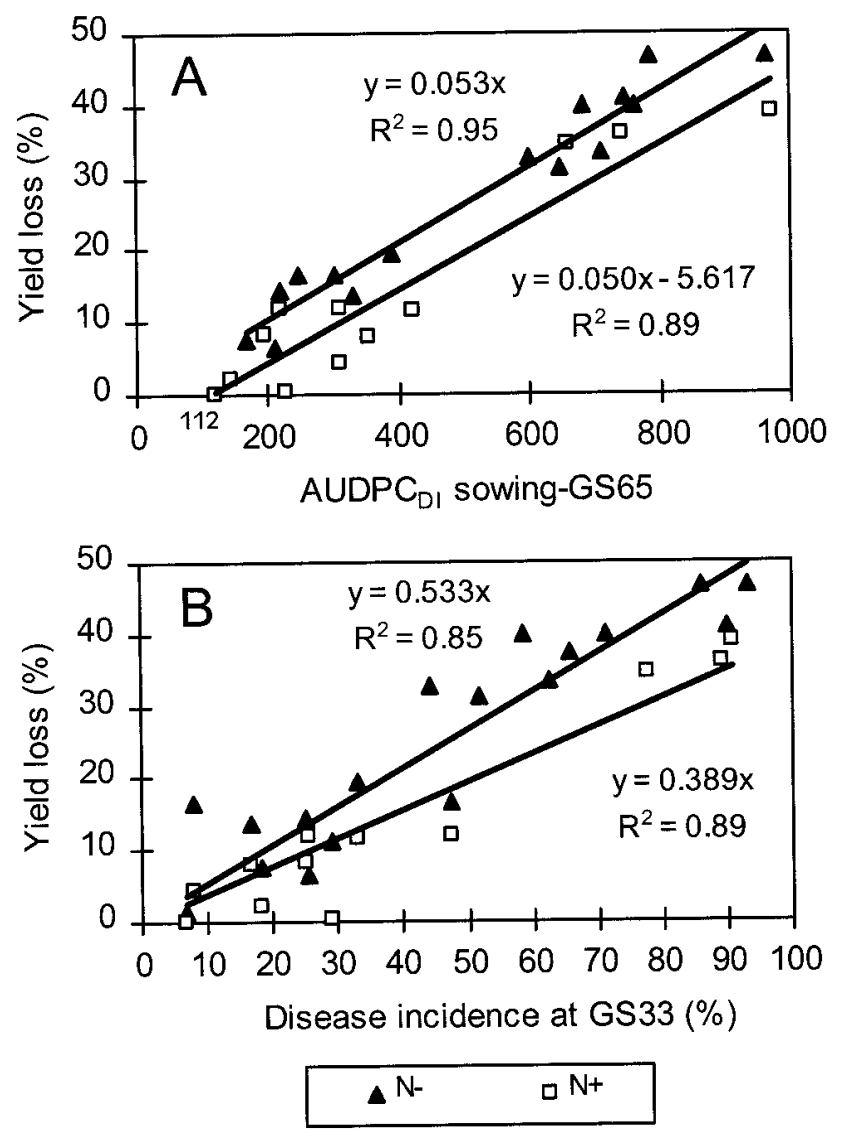

Fig. 4. Disease-yield loss relationships established from field experiments conducted in France in 1994 to 1997. A, Yield loss function of cumulative disease incidence between sowing and flowering; and $\mathbf{B}$, yield loss function of disease incidence at midstem elongation. $\mathrm{N}-=$ low nitrogen fertilization; and $\mathrm{N}+=$ high nitrogen fertilization .
Some disease-yield relationships present a minimum non-zero disease threshold. This threshold demonstrates the existence of compensatory phenomena in root functioning, ensuring that plants are tolerant of light infections (38). Our results suggest that the minimum threshold probably varies with the nutritional status of the plant. An optimization of mineral nutrition aims to reduce the yield losses caused by the disease (5). Moore (26) has already demonstrated the usefulness of a "generous" nitrogen dressing, to assist the plant in its "struggle" with the fungus and to maintain a readily available supply of nitrogen. Rosser and Chadburn (28) suggested that nitrogen fertilizer levels should be progressively increased for successive wheat crops grown in monoculture, to compensate for the increase in disease and to maintain acceptable yields. In our experiments, losses were reduced at high levels of nitrogen fertilization for all yield components except 1,000-grain weight. This effect results either from the higher nitrogen rate or from a greater splitting of the nitrogen rate, because our experimental design did not aim at differentiating between these two assumptions. Each $1 \%$ increase in DI at midstem elongation led to a mean yield loss of $0.53 \%$ in plots with limited nitrogen fertilization (110 to $135 \mathrm{~kg}$ of $\mathrm{N}$ per ha) and of $0.39 \%$ in plots with the highest rates of nitrogen fertilizer (185 to $195 \mathrm{~kg}$ of $\mathrm{N}$ per ha). Hornby and Bateman (15) studied DI during grain filling and obtained a loss rate of $0.40 \%$ with a very high level of nitrogen fertilization (480 $\mathrm{kg}$ of $\mathrm{N}$ per ha).

The disease-yield relationships established in our study are interesting and, with additional experimental data to extrapolate them to other areas, they could be used by seed breeders for assessment of the tolerance of cultivars, and by phytopathologists for assessing the efficacy of a cultural method, a chemical treatment or a combination of methods. Disease incidence at midstem elongation could also be used by farmers as a decision-making tool for estimating yield loss after assessing the level of take-all in the field, and possibly adapting crop management. The farmer could, for instance, adjust the fungicide program (against foliar pathogens) if the estimated loss is very high, or modify the nitrogen fertilization strategy. The relevance of a greater splitting of the nitrogen dose should, however, be considered with respect to the ability of the infected plants to take up nitrogen. Knowledge of the effects of take-all on nitrogen uptake is therefore required. The effects of take-all on grain quality (e.g., protein content, protein quality, and Hagberg falling number) also remain to be determined.

\section{ACKNOWLEDGMENTS}

This work was financed by DGER/Ministère de l'Agriculture, INRA and Monsanto Europe S.A. We thank S. Carrillo for technical assistance, D. Andrivon for linguistic improvement, and the senior editor and the reviewers for helpful comments and suggestions on the manuscript.

\section{LITERATURE CITED}

1. Bateman, G. L., Hornby, D., and Gutteridge, R. J. 1990. Effects of takeall on some aspects of grain quality of winter wheat. Aspects Appl. Biol. 25:339-348.

2. Beale, R. E., Lavier, B., Becker, J., Leaper, D., and Stafford, N. B. 1998. A model for the prediction of yield loss in wheat due to take-all disease caused by Gaeumannomyces graminis var. tritici. Pages 1035-1040 in: 1998 Brighton Conference - Pests and Diseases. Brit. Crop Prot. Counc. Symp. Proc., Farnham, Surrey, U.K.

3. Beale, R. E., Phillion, D. P., Headrick, J. M., O'Reilly, P., and Cox, J. 1998. MON65500: A unique fungicide for the control of take-all in wheat. Pages 343-350 in: 1998 Brighton Conference - Pests and Diseases. Brit. Crop Prot. Counc. Symp. Proc., Farnham, Surrey, U.K.

4. Brancourt-Hulmel, M., Lecomte, C., and Meynard, J.-M. 1999. A diagnosis of yield-limiting factors on probe genotypes for characterizing environments in winter wheat trials. Crop Sci. 39:1798-1808.

5. Brennan, R. F. 1993. Effect of ammonium chloride, ammonium sulphate and sodium nitrate on take-all and grain yield of wheat grown on soils in south-western Australia. J. Plant Nutr. 16:349-358. 
6. Chevalier-Gérard, C., Denis, J. B., and Meynard, J. M. 1994. Perte de rendement due aux maladies cryptogamiques sur blé tendre d'hiver. Construction et validation d'un modèle de l'effet du système de culture. Agronomie 14:305-318.

7. Colbach, N., and Huet, P. 1995. Modelling the frequency and severity of root and foot diseases in winter wheat monocultures. Eur. J. Agron. 4:217-227

8. Colbach, N., Lucas, P., and Meynard, J.-M. 1997. Influence of crop management on take-all development and disease cycles on winter wheat. Phytopathology 87:26-32.

9. Cook, R. J. 1981. The influence of rotation crops on take-all decline phenomenon. Phytopathology 71:189-192.

10. Folwell, R. J., Cook, R. J., Heim, M. N., and Moore, D. L. 1991. Economic significance of take-all on winter wheat in the Pacific Northwest USA. Crop Prot. 10:391-395.

11. Gate, P. 1995. Ecophysiologie du blé. De la plante à la culture. Tec. Doc. Lavoisier, Paris.

12. Girard, M.-L. 1997. Modélisation de l'accumulation de biomasse et d'azote dans les grains de blé tendre d'hiver (Triticum aestivum L.). Simulation de leur teneur en protéines à la récolte. Ph.D thesis. Institut National de Recherche Agronomique, Paris-Grignon.

13. Green, C. F., and Ivins, J. D. 1984. Late infestations of take-all (Gaeumannomyces graminis var. tritici) on winter wheat (Triticum aestivum cv. Virtue): Yield, yield components and photosynthetic potential. Field Crops Res. 8:199-206.

14. Hornby, D. 1979. Take-all decline: A theorist's paradise. Pages 133-156 in: Soil-Borne Plant Pathogens. B. Schippers and W. Gams, eds. Academic Press, New York.

15. Hornby, D., and Bateman, G. L. 1990. Artificial infestation of soil with Gaeumannomyces graminis var. tritici to study the relationship between take-all and wheat yields in field experiments. Soil Use Manag. 6:209217.

16. Hornby, D., Bateman, G. L., Gutteridge, R. J., Lucas, P., Osbourn, A. E., Ward, E., and Yarham, D. J. 1998. Take-all Disease of Cereals. A Regional Perspective. CAB International, Wallingford, U.K.

17. Jeuffroy, M.-H., and Bouchard, C. 1999. Intensity and duration of nitrogen deficiency on wheat grain number. Crop Sci. 39:1385-1393.

18. Langer, R. H. M., and Liew, F. K. Y. 1973. Effects of varying nitrogen supply at different stages of the reproductive phase on spikelet and grain production and on grain nitrogen in wheat. Aust. J. Agric. Res. 24:647-656.

19. Lemaire, J. M., and Coppenet, M. 1968. Influence de la succession céréalière sur les fluctuations de la gravité du piétin-échaudage (Ophiobolus graminis Sacc.). Ann. Epiphyties 19:589-599.

20. Mackown, C. T., and Van Sanford, D. A. 1988. Nitrogen allocation with altered sink demand in wheat. Crop Sci. 28:133-136.

21. MacNish, G. C., and Dodman, R. L. 1973. Relation between incidence of Gaeumannomyces graminis var. tritici and grain yield. Aust. J. Biol. Sci. 26:1289-1299.

22. Masle, J. 1985. Competition among tillers in winter wheat: Consequences for growth and development of the crop. Pages 33-54 in: Wheat Growth and Modeling. W. Day and R. K. Atkin, eds. Plenum Press, New York.

23. Meynard, J.-M. 1985. Les besoins en azote du blé d'hiver jusqu'au début de la montaison. Agronomie 5:579-589.

24. Meynard, J.-M., Ribeyre, C., Boudon, O., and Laurent, E. 1988. Pour mieux connaître les variétés de blé: Analyser l'élaboration du rendement.
Perspect. Agric. 131:17-24.

25. Meynard, J.-M., and Sebillotte, M. 1994. L'élaboration du rendement du blé, base pour l'étude des autres céréales à talles. Pages 31-51 in: Elaboration du Rendement des Principales Cultures Annuelles. L. Combe and D. Picard, eds. INRA, Paris.

26. Moore, W. 1948. Take-all of cereals in England and the epidemic of 1948. Agriculture 55:383-385.

27. Rémy, J. C., and Hébert, J. 1977. Le devenir des engrais azotés dans le sol. C. R. Acad. Agric. Fr. 63:700-710.

28. Rosser, W. R., and Chadburn, B. L. 1968. Cereal diseases and their effects on intensive wheat cropping in the east midland region, 1963-65. Plant Pathol. 17:51-60.

29. Rothrock, C. S. 1988. Relative susceptibility of small grains to take-all. Plant Dis. 72:883-886.

30. Schoeny, A., and Lucas, P. 1999. Modeling of take-all epidemics to evaluate the efficacy of a new seed-treatment fungicide on wheat. Phytopathology 89:954-961.

31. Sebillotte, M. 1988. Raisonnement des itinéraires techniques par objectifs de rendement: Intérêt de l'agrophysiologie. Perspect. Agric. 129:7-16.

32. Shipton, P. J. 1975. Yield trends during take-all decline in spring barley and wheat grown continuously. EPPO Bull. 5:363-374.

33. Shipton, P. J., Cook, R. J., and Sitton, J. W. 1973. Occurrence and transfer of a biological factor in soil that suppresses take-all of wheat in eastern Washington. Phytopathology 63:511-517.

34. Slope, D. B., and Etheridge, J. 1971. Grain yield and incidence of takeall (Ophiobolus graminis Sacc.) in wheat grown in different crop sequences. Ann. Appl. Biol. 67:13-22.

35. Smiley, R. W., and Cook, R. J. 1973. Relationship between take-all of wheat and rhizosphere $\mathrm{pH}$ in soils fertilized with ammonium vs. nitratenitrogen. Phytopathology 63:882-890.

36. Spiertz, J. H. J., and Ellen, J. 1978. Effects of nitrogen on crop development and grain growth of winter wheat in relation to assimilation and utilization of assimilates and nutrients. Neth. J. Agric. Sci. 26:210-231.

37. Spink, J. H., Wade, A. P., Paveley, N. D., Griffin, J. M., Scott, R. K., and Foulkes, M. J. 1998. The effects of a novel seed treatment, MON65500, on take-all severity and crop growth in winter wheat. Pages 913-920 in: 1998 Brighton Conference - Pests and Diseases. Brit. Crop Prot. Counc. Symp. Proc., Farnham, Surrey, U.K.

38. Teng, P. S. 1985. Construction of predictive models II. Forecasting crop losses. Pages 179-206 in: Mathematical Modelling of Crop Disease. C. A. Gilligan, ed. Academic Press, London.

39. Tivoli, B., Béasse, C., Lemarchand, E., and Masson, E. 1996. Effect of ascochyta blight (Mycosphaerella pinodes) on yield components of single pea (Pisum sativum) plants under field conditions. Ann. Appl. Biol. 129:207-216.

40. Wenz, M., Russell, P. E., Löchel, A. M., Buschhaus, H., Evans, P. H., Bardsley, E., Petit, F., and Puhl, T. 1998. Seed treatment with fluquinconazole for control of cereal take-all, foliar and seed-borne diseases. Pages 907-912 in: 1998 Brighton Conference - Pests and Diseases. Brit. Crop Prot. Counc. Symp. Proc., Farnham, Surrey, U.K.

41. Whingwiri, E. E., and Kemp, D. R. 1980. Spikelet development and grain yield of the wheat ear in response to applied nitrogen. Aust. J. Agric. Res. 31:637-647.

42. Zadoks, J. C., Chang, T. T., and Konzak, C. F. 1974. A decimal code for the growth stages of cereals. Weed Res. 14:415-421. 